\title{
ANALISA SIFAT AIR INJEKSI BERDASARKAN PARAMETER pH, TSS, TDS, DO DAN KESADAHAN
}

\author{
ANALYSIS OF THE PROPERTIES OF WATER INJECTION \\ BASED ON $\mathrm{pH}$, TSS, TDS, DO AND ERROR PARAMETERS
}

\author{
Euis Kusniawati ${ }^{1)}$, Hendra Budiman ${ }^{2)}$ \\ ${ }^{1) D}$ Program Studi Teknik Analisis Laboratorium Migas Politeknik Akamigas Palembang, 30257, Indonesia \\ ${ }^{2)}$ Program Studi Teknik Eksplorasi Produksi Migas Politeknik Akamigas Palembang, 30257, Indonesia \\ Corresponding Author E-mail: euis@pap.ac.id dan hendra_budiman@pap.ac.id
}

\begin{abstract}
Formation water is water that is contained in a certain depositional environment. Formation water analysis is useful for knowing the chemical and physical properties as well as the ions in it. The problem that often occurs in formation water is whether or not the formation water is feasible or not as a result of oil and gas production exploration activities being reinjected. The analytical method used for formation water research is adjusted to the parameters to be analyzed. From the results of the tests and analyzes that have been carried out, the lowest degree of acidity $(\mathrm{pH})$ is 8.69 with a standard $\mathrm{pH}$ range of quality standards allowed for injection water, namely 6-8. The lowest Total Solid Suspended is $258.6667 \mathrm{ppm}$ from the allowable TSS value range of less than $0.2 \mathrm{ppm}$. The total dissolved solid obtained was $21,843.88 \mathrm{ppm}$, from the range of TDS values allowed for exploration activities of $4000 \mathrm{ppm}$. From the resulting hardness value from the analysis of $0.84 \mathrm{ppm}$ for total hardness and $0.1 \mathrm{ppm}$ for calcium hardness, where the minimum allowable hardness value is $500 \mathrm{ppm}$. And the dissolved oxygen obtained from the analysis is $1.6 \mathrm{ppm}$ from 0.2 ppm permissible DO levels. Thus, the injection water contained in the Odira Energy Karang Agung PSC is not yet suitable for use as injection water.
\end{abstract}

Keywords: Injection water, pH, TDS, TSS, DO, hardness

Abstrak: Air formasi adalah air yang terdapat dalam suatu lingkungan pengendapan tertentu. Analisa air formasi berguna untuk mengetahui sifat kimia dan sifat fisikadan juga ion-ion yang ada di dalamnya. Permasalahan yang sering terjadi dalam air formasi adalah layak atau tidaknya air formasi yang dihasilkan dari kegiatan eksplorasi produksi migas diinjeksikan kembali. Metode analisa yang digunakan untuk penelitin air formasi disesuaikan dengan parameter yang akan dilakukan analisa. Dari hasil pengujian dan analisa yang telah dilakukan diperoleh derajat keasaman $(\mathrm{pH})$ terendah 8,69 dengan range pH standar baku mutu yang diperbolehkan untuk air injeksi yaitu 6-8. Untuk Total Solid Suspended terendah yang diperoleh, yaitu 258,6667 ppm dari range nilai TSS yang diperbolehkan kurangdari 0,2 ppm. Total dissolved solid yang diperoleh sebesar 21.843,88 ppm, dari range nilai TDS yang diperbolehkan untuk kegiatan eksplorasi sebesar 4000 ppm. Dari nilai kesadahan yang dihasilkan dari analisa sebesar 0,84 ppm untuk total hardness dan 0,1 ppm untuk calcium hardness, dimana nilai kesadahan minimun yang diperbolehkan sebesar 500 ppm. Dan dissolved oksigen yang diperoleh dari hasil analisa sebesar 1,6 ppm darinilai 0,2 ppm kadar DO yang diperbolehkan. Dengan demikian, air injeksi yang terdapat di PSC.Odira Energy Karang Agung belum layak untukdigunakan sebagai air injeksi.

Kata kunci : Air injeksi, pH, TDS, TSS, DO, kesadahan

\section{PENDAHULUAN}

Air formasi adalah air yang berada dalam suatu lingkungan pengendapan tertentu, air ini didapat pada saat proses pengeboran atau produksi minyak dan gas bumi. Penanganan permasalahan air timbul dari sifat air yang merupakan pelarut yang sangat baik. Air dari bawah permukaan banyak berhubungan dengan tanah dan batuan formasi dan akan melarutkan beberapa senyawa, selain itu juga akan mengandung padatan tersuspensi dan beberapa gas yang terlarut didalamnya. Air juga dapat melarutkan beberapa jenis logam. Mikroba juga akan lebih cepat tumbuh dalam media air. Perubahan tekanan dan temperatur juga akan merubah senyawa yang terlarut sehingga akan terjadi pengendapan.

Analisa air formasi berguna untuk mengetahui sifat kimia dan sifat fisika dan juga ion-ion yang ada di dalamnya. $\mathrm{pH}$, temperatur, total dissolved solid, dissolved 
oksigen, total suspended solid, warna air dan kesadahan.

Penelitian mengenai air formasi sudah sering dilakukan. Beberapa penelitian yang berhubungan dengan air injeksi diantaranya adalah analisis pengaruh injeksi air terproduksi pada kegiatan pressure maintenance terhadap kualitas air tanah yang dilakukan oleh Bobby Andrian Sitorus, pada penelitian ini didapatkan hasil bahwa sampel dengan parameter $\mathrm{pH}$, Besi (Fe), Mangan (Mn), Timbal $(\mathrm{Pb})$ didapatkan $\mathrm{pH}$ 5,17 -7,32, Besi (Fe) berkisar antara 0,153-1,634 $\mathrm{mg} / \mathrm{l}$, Mangan (Mn) 0,0074-0,0554 mg/l dan Timbal (Pb) 0,0027. Penelitian lain mengenai air injeksi dilakukan oleh Yuniarto mengenai dampak limbah cair panas bumi dan dampaknya terhadap lingkungan. Dari penelitian ini didapatkan hasil bahwa pembuangan limbah cair panas bumi tidak memberikan dampak ke lingkungan. Penelitian lain yang dilakukan terhadap air injeksi adalah penelitian yang dilakukan oleh Tri Partuti mengenai efektivitas resin penukar kation untuk menurunkan kadar total dissolved (TDS) dalam limbah air terproduksi industri migas. Dari penelitian ini didapatkan hasil bahwa semakin tinggi konsentrasi TDS konsentrasi TDS dalam limbah air terproduksi semakin cepat proses pertukaran ion terjadi dan semakin cepat resin menjadi jenuh. Penelitian lainnya mengenai air injeksi adalah Karakterisasi Air Terproduksi Industri Migas Sebagai Sumber Daya Air Alternatif Di Kecamatan Minas, Kabupaten Siak, Riau. Yang dilakukan oleh Maulana Hadi. Dari penelitian ini didapatkan hasil bahwa Berdasarkan 46 parameter pengujian laboratorium yang disyaratkan pada PP 82/2001 untuk golongan 1 (air minum), untuk air terproduksi industri migas di wilayah Kecamatan Minas, masih terdapat 17 parameter $(37 \%)$ belum memenuhi baku mutu. Sedangkan untuk kualitas air masyarakat, untuk air minum dari depot isi ulang mempunyai 4 parameter yang belum masuk dalam baku mutu (9\%) dan untuk air yang dari sumur masyarakat masih mempunyai 3 parameter yang belum masuk baku mutu (7\%).
Penelitian lain mengenai air injeksi yaitu analisis pengolahan air terinjeksi di water treating plant perusahaan eksploitasi minyak bumi oleh pertiwi andarani, hasil penelitian ini diperoleh bahwa Berdasarkan hasil analisa, API Separator sudah memenuhi kriteria desain untuk beban permukaan (surface loading), tetapi untuk kecepatan horizontal pada pit\#A lebih tinggi dibandingkan dengan kriteria desain. Berdasarkan hasil perhitungan, efisiensi penyisihan OC pada MFU adalah berkisar 96-98\%, sedangkan turbiditas adalah berkisar 94-98\%. Efisiensi penyisihan OC pada ORF 60 - 65\% (belum memenuhi standar operasi), penyisihan turbiditas $47-59 \%$. Efisiensi penyisihan kesadahan (hardness) pada softener mencapai $99 \%$.

Dari beberapa penelitian yang telah dilakukan di atas, belum ada yang membahas secara spesifik kualitas air injeksi berdasarkan parameter $\mathrm{pH}$, TDS, TSS, DO dan kesadahan sehingga dilakukan penelitian mengeani hal tersebut.

\subsection{Batasan Masalah}

Untuk memfokuskan penelitian yang dilakukan pada analisa sifat air injeksi ini, penulis membatasi ruang lingkup permasalahan pada analisa sifat air injeksi berdasarkan parameter $\mathrm{pH}$, TSS, TDS, DO dan kesadahan dari air terproduksi dari lapangan PSC Odira Energy Karang Agung yang dilakukan pengujian di laboratorium Limbah Politeknik Akamigas Palembang

\subsection{Tujuan Penelitian}

Tujuan dari penelitian ini adalah untuk mengetahui untuk mengetahui layak atau tidak air formasi yang terdapat pada PSC Odira Energy Karang Agung untuk diinjeksikan kembali.

\subsection{Manfaat Penelitian}

Manfaat yang diharapkan dari hasil penelitian ini adalah untuk mengetahui kondisi air formasi sehingga mempertahankan kualitas terbaik dari air formasi sebelum dilakukan injeksi seperti: 
1. Dapat mengoperasikan peralatan yang digunakan selama pengujian analisa air formasi dilakukan

2. Dapat memahami parameter yang digunakan dalam menganalisa air formasi

3. Dapat mengetahui standar kualitas air injeksi yang digunakan sesuai baku mutu yang digunakan.

\section{TEORI DASAR}

\subsection{Air Formasi}

Air formasi adalah air yang terdapat dalam suatu lingkungan pengendapan tertentu. Semula air formasi dikenal dengan istilah oilfield brine yang diduga berasal dari air atmosfer yang masuk ke dalam sedimen. Namun kemudian mengingat sifat asin yang ada pada air tersebut, maka diduga air tersebut berasal dari air laut yang ikut terendapkan dengan sedimen disekelilingnya. Sehingga dikenal istilah baru, yaitu air interestial, yang berarti air yang ditemui pada saat pengeboran minyak dan tidak mempersoalkan asal usulnya.

Kinghorn (1984) menegaskan bahwa air formasi adalah air yang terjadi secara alamiah dan telah ada pada batuan sedimen sebelum dibor, yang bersifat asin, tawar atau payau. Pada umumnya air murni mempunyai sifat fisik antara lain: berat atom $=18$, densitas $=1 \mathrm{~g} / \mathrm{ml}$, titik beku $=32{ }^{\circ} \mathrm{F}\left(0{ }^{\circ} \mathrm{C}\right)$ dan titik didih $=212{ }^{\circ} \mathrm{F}\left(100{ }^{\circ} \mathrm{C}\right)$.

Penanganan masalah air timbul dari sifat air yang merupakan pelarut yang sangat baik. Air dari bawah permukaan banyak berhubungan dengan tanah dan batuan formasi dan akan melarutkan beberapa senyawa, selain itu juga akan mengandung padatan tersuspensi dan beberapa gas yang terlarut di dalamnya. Air juga dapat melarutkan beberapa jenis logam. Mikroba juga akan lebih cepat tumbuh dalam media air. Perubahan tekanan dan temperatur juga akan merubah senyawa yang terlarut, sehingga akan terjadi pengendapan dan scale. Hal-hal tersebut yang menyebabkan penanganan terhadap air sangat sulit.

Air formasi dapat digunakan untuk berbagai tujuan antara lain: a. diinjeksikan ke bawah permukaan untuk meningkatkan perolehan minyak (dalam industri perminyakan),

b. dinjeksikan ke bawah permukaan untuk disposal jika air tersebut mengandung zat-zat yang berbahaya,

c. Pendingin dalam mesin gas, compressor dan lainnya.

\subsection{Parameter Penentuan Kualitas Air 2.2.1 Derajat Keasaman (pH)}

Derajat keasaman $(\mathrm{pH})$ menjadi salah satu parameter penting dalam penentuan kualitas air. Tingkat keasaman atau $\mathrm{pH}$ di suatu perairan ditentukan oleh komponenkomponen organik maupun anorganik terlarut yang mempunyai sifat asam (melepas $\mathrm{H}^{+}$) atau basa (melepas $\left.\mathrm{OH}^{-}\right)$. Besaran $\mathrm{pH}$ air berkisar dari 0 (sangat asam) sampai dengan 14 (sangat basa atau alkalis). Nilai pH kurang dari 7 menunjukkan lingkungan yang asam.

\subsubsection{Total Suspended Solid (TSS)}

Total suspended solid atau jumlah padatan tersuspensi (TSS) adalah padatan yang menyebabkan kekeruhan air, tidak terlarut dan tidak dapat langsung mengendap, terdiri dari partikel-partikel yang ukuran maupun beratnya lebih kecil dari sedimen. Misalnya minyak, endapan, tanah liat, bahan-bahan organik tertentu, sel-sel mikroorganisme dan bahan kimia yang tidak larut.

Zat padat tersuspensi dapat bersifat organis dan inorganis. Zat padat tersuspensi dapat diklasifikasikan sekali lagi menjadi antara lain zat padat terapung yang selalu bersifat organis dan zat padat terendap yang dapat bersifat organis dan inorganis. Jumlah padatan tersuspensi dapat dihitung menggunakan Gravimetri. Kandungan TSS dalam badan air sering menunjukan konsentrasi yang lebih tinggi pada bakteri, nutrien, pestisida, logam didalam air.

\subsubsection{Total Dissolved Solid (TDS)}

TDS (total dissolve solid) merupakan ukuran zat terlarut (baik itu zat organik maupun anorganik, misalnya: garam, dll.) yang terdapat pada sebuah larutan. TDS meter menggambarkan jumlah zat terlarut dalam part per million ( $\mathrm{ppm}$ ) atau sama dengan milligram 
per liter $(\mathrm{mg} / \mathrm{L})$. Umumnya berdasarkan definisi diatas seharusnya zat yang terlarut dalam air (larutan) harus dapat melewati saringan yang berdiameter 2 mikrometer $\left(2 \times 10^{-6}\right.$ meter $)$. Aplikasi yang umum digunakan adalah untuk mengukur kualitas cairan biasanya untuk pengairan, pemeliharaan aquarium, kolam renang, proses kimia, pembuatan air mineral, dll.. Setidaknya, kita dapat mengetahui air minum mana yang baik dikonsumsi tubuh, ataupun air murni untuk keperluan kimia (misalnya pembuatan kosmetika, obat-obatan, makanan, dll.). Sampai saat ini ada dua metoda yang dapat digunakan untuk mengukur kualitas suatu larutan.

\subsubsection{Kesadahan}

Kesadahan

air adalah

kandungan mineral-mineral tertentu di dalam air, umumnya ion kalsium $\left(\mathrm{Ca}^{2+}\right)$ dan magnesium $\left(\mathrm{Mg}^{2+}\right)$ dalam bentuk garam karbonat. Air sadah atau air keras adalah air yang memiliki kadar mineral yang tinggi, sedangkan air lunak adalah air dengan kadar mineral yang rendah. Selain ion kalsium dan magnesium, penyebab kesadahan juga bisa merupakan ion logam lain maupun garamgaram bikarbonat dan sulfat. Metode paling sederhana untuk menentukan kesadahan air adalah dengan sabun. Dalam air lunak, sabun akan menghasilkan busa yang banyak. Pada air sadah, sabun tidak akan menghasilkan busa atau menghasilkan sedikit sekali busa. Kesadahan air total dinyatakan dalam satuan ppm berat per volume (w/v) dari $\mathrm{CaCO}_{3}$.

Cara paling mudah untuk mengetahui air yang selalu anda gunakan adalah air sadah atau bukan yaitu dengan menggunakan sabun. Ketika air yang anda gunakan adalah air sadah, maka sabun akan sukar berbuih, kalaupun berbuih, buihnya sedikit. Kemudian untuk mengetahui jenis kesadahan air adalah dengan pemanasan. Cara yang lebih kompleks adalah melalui titrasi.

Air sadah dapat menyebabkan pengendapan mineral, yang menyumbat saluran pipa dan keran. Air sadah juga menyebabkan pemborosan sabun di rumah tangga, dan air sadah yang bercampur sabun tidak dapat membentuk busa, tetapi malah membentuk gumpalan soap scum (sampah sabun) yang sukar dihilangkan. Efek ini timbul karena ion $2^{+}$menghancurkan sifat surfaktan dari sabun dengan membentuk endapan padat (sampah sabun tersebut). Komponen utama dari sampah tersebut adalah kalsium stearat, yang muncul dari stearat natrium, komponen utama dari sabun:

$$
2 \mathrm{C}_{17} \mathrm{H}_{35} \mathrm{COO}^{-}+\mathrm{Ca}^{2+} \rightarrow\left(\mathrm{C}_{17} \mathrm{H}_{35} \mathrm{COO}\right)_{2} \mathrm{Ca}
$$

Kesadahan total yaitu ion $\mathrm{Ca}^{2+}$ dan $\mathrm{Mg}^{2+}$ dapat ditentukan melalui titrasi dengan EDTA sebagai titran dan menggunakan indikator yang peka terhadap semua kation tersebut. Kejadian total tersebut dapat dianalisis secara terpisah misalnya dengan metode AAS (Automic Absorption Spectrophotometry).

Asam Ethylenediaminetetraacetic dan garam sodium ini (singkatan EDTA) bentuk satu kompleks kelat yang dapat larut ketika ditambahkan ke suatu larutan yang mengandung kation logam tertentu. Jika sejumlah kecil Eriochrome Hitam $\mathrm{T}$ atau Calmagite ditambahkan ke suatu larutan mengandung kalsium dan ion-ion magnesium pada satu $\mathrm{pH}$ dari $10,0 \pm 0,1$, larutan menjadi berwarna merah muda. Jika EDTA ditambahkan sebagai satu titran, kalsium dan magnesium akan menjadi suatu kompleks, dan ketika semua magnesium dan kalsium telah manjadi kompleks, larutan akan berubah dari berwarna merah muda menjadi berwarna biru yang menandakan titik akhir dari titrasi. Ion magnesium harus muncul untuk menghasilkan suatu titik akhir dari titrasi. Untuk mememastikan ini, kompleks garam magnesium netral dari EDTA ditambahkan ke larutan buffer.

Penentuan $\mathrm{Ca}$ dan $\mathrm{Mg}$ dalam air sudah dilakukan dengan titrasi EDTA. $\mathrm{pH}$ untuk titrasi adalah 10 dengan indikator Eriochrom Black $\mathrm{T}$ (EBT). Pada $\mathrm{pH}$ lebih tinggi 12, $\mathrm{Mg}(\mathrm{OH})_{2}$ akan mengendap, sehingga EDTA dapat dikonsumsi hanya oleh $\mathrm{Ca}^{2+}$ dengan indikator murexide. Adanya gangguan $\mathrm{Cu}$ 
bebas dari pipa-pipa saluran air dapat di masking dengan $\mathrm{H}_{2} \mathrm{~S}$. EBT yang dihaluskan bersama $\mathrm{NaCl}$ padat kadangkala juga digunakan sebagai indikator untuk penentuan $\mathrm{Ca}^{2+}$ ataupun hidroksinaftol. Seharusnya $\mathrm{Ca}^{2+}$ tidak ikut terkopresitasi dengan $\mathrm{Mg}^{2+}$, oleh karena itu EDTA direkomendasikan.

Kejelasan dari titik akhir banyak dengan $\mathrm{pH}$ peningkatan. Bagaimanapun, $\mathrm{pH}$ tidak dapat ditingkat dengan tak terbatas karena akibat bahaya dengan kalsium karbonat mengendap, $\mathrm{CaCO}_{3}$, atau hidroksida magnesium, $\operatorname{Mg}(\mathrm{OH})_{2}$, dan karena perubahan celup warnai di ketinggian $\mathrm{pH}$ hargai. Ditetapkan $\mathrm{pH}$ dari 10,0 \pm 0,1 adalah satu berkompromi kepuasan. Satu pembatas dari 5 min disetel untuk jangka waktu titrasi untuk memperkecil kecenderungan ke arah $\mathrm{CaCO}_{3}$ pengendapan.

\subsubsection{Dissolved Oxygen (DO)}

Oksigen terlarut (dissolved oxygen, disingkat DO) atau sering juga disebut dengan kebutuhan oksigen (oxygen demand) merupakan salah satu parameter penting dalam analisis kualitas air. Nilai DO yang biasanya diukur dalam bentuk konsentrasi ini menunjukan jumlah oksigen $\left(\mathrm{O}_{2}\right)$ yang tersedia dalam suatu badan air. Semakin besar nilai DO pada air ,mengindikasikan air tersebut memiliki kualitas yang bagus. Sebaliknya jika nilai DO rendah, dapat diketahui bahwa air tersebut telah tercemar. Pengukuran DO juga bertujuan melihat sejauh mana badan air mampu menampung biota air seperti ikan dan mikroorganisme. Selain itu, kemampuan air untuk membersihkan pencemaran juga ditentukan oleh banyaknya oksigen dalam air.

Oksigen terlarut merupakan kebutuhan yang vital bagi kelangsungan hidup organisme suatu perairan. Oksigen terlarut diambil oleh organisme perairan melalui respirasi untuk pertumbuhan, reproduksi, dan kesuburan. Menurunnya kadar oksigen terlarut dapat mengurangi efesien pengambilan oksigen oleh biota laut, sehingga dapat menurunkan kemampuan untuk hidup normal dalam lingkungan hidupnya. Umumnya oksigen dijumpai di lapisan permukaan karena oksigen dari udara di dekatnya dapat secara langsung larut (berdifusi ke dalam air laut). Phytoplankton juga membantu meningkatkan kadar oksigen terlarut pada siang hari. Penambahan ini disebabkan oleh terlepasnya gas oksigen sebagai hasil fotosintesis (Hutabarat dan Evans, 1984).

Oksigen terlarut diambil oleh organisme perairan melalui respirasi untuk pertumbuhan, reproduksi, dan kesuburan. Menurunnya kadar oksigen terlarut dapat mengurangi efesiensi pengambilan oksigen oleh biota laut, sehingga dapat menurunkan kemampuan untuk hidup normal dalam lingkungan hidupnya (Hutabarat dan Evans, 1984).

Kandungan oksigen terlarut $2 \mathrm{mg} / \mathrm{L}$ adalah kandungan minimal yang cukup untuk mendukung kehidupan organisme perairan secara normal. Agar kehidupan dapat layak dan kegiatan perikanan berhasil maka kandungan oksigen terlarut harus tidak boleh kurang daripada 4 ppm sedangkan perairan mengandung $5 \mathrm{mg} / \mathrm{L}$ oksigen pada suhu 20-30 ${ }^{\circ} \mathrm{C}$ masih dipandang sebagi air yang cukup baik untuk kehidupan ikan (Ismail, 1994).

\subsection{Faktor-faktor yang Mempengaruhi Proses Pengendapan}

Keberhasilan proses pengendapan sangat dipengaruhi oleh berbagai macam faktor diantaranya temperatur, sifat alami pelarut, pengaruh ion lain, $\mathrm{pH}$, hidrolisis dan pembentukan kompleks. Pengaruh ini dapat kita jadikan sebagai dasar untuk memahami titrasi argentometri dan gravimetri.

1. Temperatur

Kelarutan semakin meningkat dengan naiknya suhu. Jadi, dengan meningkatnya suhu maka pembentukan endapan akan berkurang disebabkan banyak endapan yang berada pada larutannya.

2. Sifat alami pelarut

Garam anorganik mudah larut dalam air dibandingkan dengan pelarut organik seperti alkohol atau asam asetat. Perbedaan kelarutan suatu zat dalam pelarut organik dapat dipergunakan untuk memisahkan campuran antara dua zat. Setiap pelarut memiliki kapasitas yang berbeda dalam 
melarutkan suatau zat, begitu juga dengan zat yang berbeda memiliki kelarutan yang berbeda pada pelarut tertentu.

\section{Pengaruh ion sejenis}

Kelarutan endapan akan berkurang jika dilarutkan dalam larutan yang mengandung ion sejenis dibandingkan dalam air saja. Sebagai contoh kelarutan $\mathrm{Fe}(\mathrm{OH})_{3}$ akan menjadi kecil jika kita larutkan dalam larutan $\mathrm{NH}_{4} \mathrm{OH}$ dibanding dengan kita melarutkannya dalam air, hal ini disebabkan dalam larutan $\mathrm{NH}_{4} \mathrm{OH}$ sudah terdapat ion sejenis, yaitu $\mathrm{OH}^{-}$ sehingga akan mengurangi konsentrasi $\mathrm{Fe}(\mathrm{OH})_{3}$ yang akan terlarut. Efek ini biasanya dipakai untuk mencuci endapan dalam metode gravimetri.

\section{Pengaruh $\mathrm{pH}$}

Kelarutan endapan garam yang mengandung anion dari asam lemah dipengaruhi oleh $\mathrm{pH}$, hal ini disebabkan karena penggabungan proton dengan anion endapannya. Misalnya endapan AgI akan semakin larut dengan adanya kenaikan $\mathrm{pH}$ disebabkan $\mathrm{H}^{+}$akan bergabung dengan $\mathrm{I}^{-}$ membentuk HI.

\section{Pengaruh hidrolisis}

Jika garam dari asam lemah dilarutkan dalam air maka akan dihasilkan perubahan konsentrasi $\mathrm{H}^{+}$dimana hal ini akan menyebabkan kation garam tersebut mengalami hidrolisis dan hal ini akan meningkatkan kelarutan garam tersebut.

6. Pengaruh ion kompleks

Kelarutan garam yang tidak mudah larut akan semakin meningkat dengan adanya pembentukan kompleks antara ligan dengan kation garam tersebut. Sebagai contoh $\mathrm{AgCl}$ akan naik kelarutannya jika ditambahkan larutan $\mathrm{NH}_{3}$, hal ini disebabkan karena terbentuknya kompleks $\mathrm{Ag}\left(\mathrm{NH}_{3}\right)_{2} \mathrm{Cl}$.

\section{Metode Fajans}

Indikator adsorbsi dapat dipakai untuk titrasi argentometri. Titrasi argentometri yang menggunakan indicator adsorbsi ini dikenal dengan sebutan titrasi argentometri metode Fajans. Sebagai contoh marilah kita gunakan titrasi ion klorida dengan larutan standart $\mathrm{Ag}^{+}$. Dimana hasil reaksi dari kedua zat tersebut adalah:

$$
\mathrm{Ag}_{(\mathrm{aq})}^{+}+\mathrm{Cl}_{(\mathrm{aq})}^{-} \rightarrow \mathrm{AgCl}_{(\mathrm{s})} \text { (endapan putih) }
$$

Endapan perak klorida membentuk endapan yang bersifat koloid. Sebelum titik ekuivalen dicapai maka endapat akan bermuatan negative disebakkan teradsorbsinya $\mathrm{Cl}^{-}$di seluruh permukaan endapan. Dan terdapat counter ion bermuatan positif dari $\mathrm{Ag}^{+}$yang teradsorbsi dengan gaya elektrostatis pada endapat. Setelah titik ekuivalen dicapai maka tidak terdapat lagi ion $\mathrm{Cl}^{-}$yang teradsorbsi pada endapan sehingga endapat sekarang bersifat netral.

Kelebihan ion $\mathrm{Ag}^{+}$yang diberikan untuk mencapai titik akhir titrasi menyebabkan ion-ion $\mathrm{Ag}^{+}$ini teradsorbsi pada endapan sehingga endapan bermuatan positif dan beberapa ion negative teradsorbsi dengan gaya elektrostatis sebagai counter ion. Indikator adsorbsi merupakan pewarna, seperti diklorofluorescein yang berada dalam keadaan bermuatan negative dalam larutan titrasi akan teradsorbsi sebagai counter ion pada permukaan endapan yang bermuatan positif. Dengan terserapnya ini, maka warna indicator akan berubah dimana warna diklorofluorescein menjadi berwarna merah muda.

\subsection{Baku Mutu Air Limbah Kegiatan Eksplorasi dan Produksi Migas dari Fasilitas Produksi (On-Shore) Baru \\ Mengingat bahwa pelaksanaan} kegiatan penginjeksian air didalam dunia industri perminyakan ini dapat atau berpotensi menimbulkan pencemaran ataupun kerusakan, baik itu terhadap lingkungan, peralatan yang digunakan maupun pada formasi penginjeksian. Maka dalam pelaksanaan kegiatan penginjeksian air ini diperlukan suatu peraturan atau baku mutu standar untuk air yang akan diinjeksikan. Di Indonesia peraturan atau baku mutu standar yang dipakai untuk air injeksi yang digunakan dalam kegiatan penginjeksian air diatur didalam Peraturan Menteri Negara Lingkungan Hidup Nomor 19 Tahun 2010 Tentang Baku Mutu Air Limbah Kegiatan Eksplorasi dan Produksi Migas dari Fasilitas Produksi (on-shore) yang dapat dilihat pada Tabel 2.1. 
Tabel 2.1 Baku Mutu Air Limbah Kegiatan Eksplorasi Produksi Migas

\begin{tabular}{|c|c|c|c|c|}
\hline NO. & $\begin{array}{c}\text { JENIS AIR } \\
\text { LIMBAH }\end{array}$ & PARAMETER & $\begin{array}{c}\text { KADAR } \\
\text { MAKSIMUM }\end{array}$ & $\begin{array}{l}\text { METODE } \\
\text { PENGUKURAN }\end{array}$ \\
\hline \multirow[t]{8}{*}{1.} & \multirow[t]{8}{*}{ Air Terproduksi } & COD & $200 \mathrm{mg} / \mathrm{L}$ & $\begin{array}{c}\text { SNI 06-6989:2-2004 } \\
\text { atau } \\
\text { SNI 06-6989:15-2004 } \\
\text { atau APHA 5220 }\end{array}$ \\
\hline & & Minvak dan Lemak & $25 \mathrm{mg} / \mathrm{L}$ & SNI 06-6989.10-2004 \\
\hline & & $\begin{array}{l}\text { Sulfida Terlarut } \\
\text { (sebagai } \mathrm{H}_{2} \mathrm{~S} \text { ) }\end{array}$ & $0,5 \mathrm{mg} / \mathrm{L}$ & $\begin{array}{l}\text { SNI 06-2470-1991 } \\
\text { atau APHA 4500-S }\end{array}$ \\
\hline & & $\begin{array}{l}\text { Amonia (sebagai } \\
\text { NH3-N) }\end{array}$ & $5 \mathrm{mg} / \mathrm{L}$ & $\begin{array}{l}\text { SNI 06-6989.30-2005 } \\
\text { atau APHA 4500-NH3 }\end{array}$ \\
\hline & & Phenol Total & $2 \mathrm{mg} / \mathrm{L}$ & SNI 06-6989.21-2005 \\
\hline & & Temperatur & $40^{\circ} \mathrm{C}$ & SNI 06-6989.23-2005 \\
\hline & & $\mathrm{pH}$ & $6-9$ & SNI 06-6989.11-2004 \\
\hline & & $\operatorname{TDS}^{(2)}$ & $4000 \mathrm{mg} / \mathrm{L}$ & SNI 06-6989.27-2005 \\
\hline \multirow[t]{2}{*}{2.} & \multirow{2}{*}{$\begin{array}{l}\text { Air Limbah } \\
\text { Drainase }\end{array}$} & Minyak dan Lemak & $15 \mathrm{mg} / \mathrm{L}$ & SNI 06-6989.10-2004 \\
\hline & & $\begin{array}{l}\text { Karbon Organik } \\
\text { Total }\end{array}$ & $110 \mathrm{mg} / \mathrm{L}$ & $\begin{array}{c}\text { SNI 06-6989.28-2005 } \\
\text { atau APHA 5310 }\end{array}$ \\
\hline
\end{tabular}

\section{METODOLOGI PENELITIAN}

\subsection{Tahapan Penelitian}

Tahapan penelitian merupakan tahapan-tahapan yang dilakukan untuk melakukan penelitian. Tahapan penelitian tersebut berupa tahapan pendahuluan, tahapan studi literatur, tahapan pengumpulan data dan tahapan pengolahan data hingga diperoleh suatu analisa dan kesimpulan mengenai sifat dan kualitas air injeksi berdasarkan standar baku mutu yang ditetapkan.

Sebelum melakukan penelitian, Penulis terlebih dahulu membuat kerangka penelitian berupa perumusan tujuan, tujuan dan permaslahan yang akan dilakukan serta diagram alir serta parameter yang akan dilakukan pengujian hingga diperoleh suatu analisa dan kesimpulan.

\subsubsection{Studi Literatur}

Studi pustaka ini dilakukan pada beberapa referensi untuk mendukung penelitian secara keilmuwan sehingga dalam pembahasannya akan ditunjang dengan dasardasar teori yang kuat. Tahap studi literatur dilakukan dengan pengumpulan sumber informasi yang berasal dari referensi manapun. Studi literatur ini dilakukan sebelum dan selama penelitian ini berlangsung.

\subsubsection{Tahap Pengumpulan Data}

Setelah mengetahui materi dasar untuk melakukan penelitian, Penulis melakukan pengumpulan data. Data-data yang dibutuhkan seperti data indikasi parameter fisika dan kimia yang dilakukan di laboratorium (analisa kualitas air injeksi).

\subsubsection{Tahap Pengujian Data}

Sampel yang diperoleh dari lapangan, diambil sebanyak $100 \mathrm{ml}$ untuk dilakukan analisa parameter yang meliputi pengukuran $\mathrm{pH}$, TSS, TDS, DO, kesadahan dan warna air.

\subsubsection{Tahap Pengolahan Data}

Pengolahan data merupakan proses pengolahan dari data-data yang diperoleh, yang selanjutnya akan dilakukan penelitian mengenai analisa kualitas air injeksi yang diolah dengan menggunakan parameter air injeksi dan juga dilakukannya analisa langsung di laboratorium yang bertujuan untuk melihat dampak yang nantinya akan dihasikan oleh air injeksi tersebut dengan menggunakan berbagai jenis metode. Merupakan proses pengolahan dari data-data yang diperoleh baik dari lapagan maupun sumber referensi lainnya, yang selanjutnya akan dilakukan penelitian mengenai analisa air formasi untuk menentukan $\mathrm{pH}$, TDS, TSS, kesadahan dan DO.

\subsection{Standar Baku Mutu Kualitas Air Injeksi}

Analisa kualitas air untuk menentukan kualitas dari air yang akan digunakan kembali untuk injeksi. Analisa ini dilakukan yakni dengan melakukan penganalisaan sampel diruang laboratorium dengan metode yang telah memenuhi standar yang ditentukan. Tidak semua analisa pada air injeksi dapat dilakukan untuk lebih meyakinkan apakah hasil yang didapatkan itu benar dan dapat melakukan pencegahan dan pengurangan masalah yang terjadi pada air injeksi.

Tabel 3.1 Parameter Standar Kualitas Air Injeksi

\begin{tabular}{|r|l|c|l|}
\hline No. & \multicolumn{1}{|c|}{ Parameter Test } & Batas & Unit \\
\hline 1 & $\mathrm{pH}$ & $6,5-8$ & \\
\hline 2 & Dissolved Oxygen & $\leq 0,2$ & $\mathrm{ppm}$ \\
\hline 3 & Bacteri & 0 & \\
\hline 4 & Oil Content & 0 & $\mathrm{ppm}$ \\
\hline 5 & Turbidity & $\leq 5$ & $\mathrm{NTU}$ \\
\hline 6 & Kecepatan & $>3,2$ & $\mathrm{ppm}$ \\
\hline 7 & Fe & $\leq 1$ & $\mathrm{ppm}$ \\
\hline 8 & Total Suspended Solid & $\leq 2$ & $\mathrm{ppm}$ \\
\hline
\end{tabular}


3.3 Prosedur Kerja Analisa Parameter Air Injeksi

3.3.1 Prosedur Analisa DO (Dissolved Oxygen)

Acuan: SNI-06-6989.14-2004 dengan metode colorimetric. Alat dan bahan yang digunakan untuk DO (Dissolved Oxygen) terdiri dari sebagai berikut :

1. Gelas kimia $25 \mathrm{ml}$,

2. Oxygen CHEMets Kit K-7501/R-7501, dan

3. Sampel lapangan.

Langkah kerja analisa DO (dissolved oxygen) sebagai berikut :

1. Ambilah sampel air dari Line-IND dan masukkan ke dalam gelas kimia sebanyak $25 \mathrm{ml}$.

2. Lalu ambilah salah satu stick yang terdapat pada oxygen chemets masukan kedalam gelas kimia yang telah diisi dengan air sampel.

3. Kemudian patahkan ujung stick lalu lihat dan samakan warna yang terdapat pada stick dengan oxygen chemets lalu catat hasilnya.

\subsubsection{Prosedur Analisa Derajat Keasaman (pH)}

Acuan: ASTM D1293-95 dengan metode potensiometric. Langkah kerja analisa Analisa Derajat Keasaman (pH) sebagai berikut :

1. Siapkan kertas $\mathrm{pH}$ meter dan sampel yang akan dianalisa.

2. Masukan kertas $\mathrm{pH}$ meter kedalam gelas ukur yang telah berisi sampel.

3. Angkat kertas $\mathrm{pH}$ meter lalu samakan warna yang didapatkan dari hasil percobaan.

4. Kemudian baca angka yang terdapat pada kertas $\mathrm{pH}$.

\subsubsection{Prosedur Analisa Total Susspended} Solid (TSS)

Acuan: SNI-06-6989.4.3-2004 dengan metode gravimetric. Alat dan bahan yang digunakan untuk analisa total suspended solid sebagai berikut:

1. Desikator yang berisi silica gel,

2. Oven,

3. Pengaduk magnetik,
4. Pipet volum,

5. Timbangan analitik,

6. Gelas ukur,

7. Cawan aluminium,

8. Penjepit,

9. Kaca arloji, dan

10. Pompa vacuum.

Langkah - langkah cara analisa pengambilan data sebagai berikut:

1. Siapkan peralatan (kertas penyaring dan backer glass) dan sampel air formasi.

2. Timbang berat kosong dari beaker glass dan kertas penyaring.

3. Masukkan sampel kedalam beaker glass dengan cara disaring menggunakan kertas penyaring (folded filter)

4. Kemudian timbang berat sampel yang masuk kedalam beaker glass dan cata hasil penimbangan.

\subsubsection{Prosedur Analisa Total Dissolved Solid (TDS)}

Acuan: SNI-06-6989.4.3-2004 dengan metode gravimetri. Alat dan bahan yang digunakan untuk melakukan analisa total dissolved solid sebagai berikut:

1. Desikator yang berisi silica gel,

2. Oven,

3. Pengaduk magnetik,

4. Pipet volum,

5. Timbangan analitik,

6. Gelas ukur,

7. Cawan aluminium,

8. Penjepit,

9. Kaca arloji,

10. Pompa vacuum, dan

11. Cawan aluminium.

Langkah - langkah cara analisa pengambilan data sebagai berikut :

1. Siapkan peralatan (oven pengering, beaker glass dan kertas penyaring) serta sampel air formasi yang telah di filter.

2. Backer glass dan kertas penyaring yang telah digunakan kemudian keringkan menggunakan oven.

3. Sampel yang berada di beaker glass telah mengering dan kertas penyaring kering, keduanya ditimbang menggunakan neraca digital. 
4. Catat hasil penimbangan sampel yang sudah kering tersebut.

\subsubsection{Prosedur Analisa Kesadahan}

Acuan: ASTM D1126-96 dengan metode colorimetric.

a. Kesadahan total (total hardness)

Alat dan bahan yang diperlukan untuk melakukan analisa kesadahan total, yaitu:

1. Erlenmeyer $100 \mathrm{ml}$,

2. Pipet volumetrik,

3. Buret mikro,

4. Larutan $\mathrm{NH}_{4} \mathrm{OH}(1+4)$,

5. Larutan $\mathrm{Na}_{2} \mathrm{CO}_{3} 3 \%$,

6. Larutan buffer $\mathrm{NH} 4 \mathrm{Cl}-\mathrm{NH} 4 \mathrm{OH}$,

7. Kalsium indicator (murexid),

8. Laruta hardness indicator,

9. Asam Klorida (1+4),

10. Larutan $\mathrm{NaOH}$,

11. Larutan standar EDTA, dan

12. Larutan $\mathrm{CaCl}_{2}$.

Prosedur analisa total hardness, yaitu:

1. Pipet $50 \mathrm{~mL}$ sampel, masukkan ke dalam erlenmeyer $100 \mathrm{ml}$.

2. Tambahkan $0,5 \mathrm{ml}$ larutan buffer dan diaduk.

3. Tambahkan 2-3 tetes larutan hardness indicator dan diaduk, biarkan selama lima menit.

4. Titrasi dengan larutan EDTA sampai tepat terjadi perubahan warna dari merah menjadi biru.

b. Kesadahan kalsium (calsium hardness)

1. Pipet $50 \mathrm{~mL}$ sampel masukkan ke dalam Erlenmeyer $100 \mathrm{ml}$.

2. Tambahkan $2 \mathrm{ml}$ larutan $\mathrm{NaOH}$ dan diaduk.

3. Tambahkan 0,2 gram Calsium indicator dan diaduk.

4. Titrasi dengan larutan EDTA sampai tepat terjadi perubahan warna dari pink menjadi purple.

\section{HASIL DAN PEMBAHASAN}

\subsection{Analisa Air Formasi}

Analisa yang digunakan untuk menentukan kadar air formasi menggunakan parameter $\mathrm{pH}$, Kesadahan, dissolve oksigen, total suspended solid (TSS), dan total dissolved solid (TDS).

\subsection{Parameter yang digunakan dalam proses analisa}

\subsubsection{Derajat Keasaman}

Merupakan salah satu indikator dari sifat suatu senyawa, yang digunaan disini adalah air formasi sebagai sampel yang akan diteliti mengenai sifat keasamannya, dengan menggunakan alat $\mathrm{pH}$ meter. Langkah kerja diawali dengan memasukan air formasi sebanyak $100 \mathrm{ml}$ kedalam baker glass, kemudian digunakan alat pengukur $\mathrm{pH}$ kedalam baker glass yang telah berisi sampel sebanyak $100 \mathrm{ml}$, maka pada monitor $\mathrm{pH}$ meter akan menunjukan angka tingkatan $\mathrm{pH}$ dari sampel yang diukur baik itu angka yang menunjukkan tingkatan asam atau pada tingkat basa.

Table 4.1 Hasil Pengukuran $\mathrm{pH}$

\begin{tabular}{|c|c|c|c|}
\hline Sampel & $\mathrm{pH}$ & Temperatur & Warna \\
\hline 1 & 8,69 & 28,7 & keruh \\
\hline 2 & 8,75 & 28,9 & keruh \\
\hline 3 & 8,77 & 28,7 & keruh \\
\hline 4 & 8,78 & 28,9 & keruh \\
\hline 5 & 8,8 & 28,8 & keruh \\
\hline 6 & 8,82 & 28,5 & keruh \\
\hline
\end{tabular}

Hasil analisa keenam sampel diatas, menunjukan nilai $\mathrm{pH}$ air formasi minimum yang diperoleh sebesar 8,69. Dari nilai $\mathrm{pH}$ yang didapat, keenam sampel tersebut bersifat basa sehingga kemungkinan terbentuknya scale cukup besar.

\subsubsection{Total Suspended Solid (TSS)}

Berbagai macam metode mengenai kelarutan padatan dalam air dapat ditentukan menggunakan metode TSS, karena padatan tersuspensi terpengaruhi dari sifat fluidanya, viskositasnya, dan ion-ionnya.

Peralatan yang digunakan dalam melakukan metode TSS ini adalah oven, kaca arloji, gelas ukur, penjepit, dan pompa vakum, sedangkan bahan yang digunakan adalah sampel formasi dan kertas saring whatman dengan ukuran 1,5 $\mu \mathrm{m}$. Hal yang dilakukan pertamakali adalah menimbang kertas saring 
dengan tujuan sebagai faktor koreksi yang akan dihitung ulang, saat hasil pengukuran telah didapat. Diawalai dengan menuangkan air formasi sebanyak $50 \mathrm{ml}$ ke wadah yang ada pada rangkaian, pada bawah wadah terdapat kertas saring untuk menahan solubility yang ada pada air formasi, serta fungsi pompa adalah menarik fluida di ruang hampa suatu wadah yang terletak di bawah kertas saring, sehingga ketika pompa menarik angin yang ada di ruang hampa akan terjadi peristiwa kapilaritas dimana air akan mengisi ruangan hampa karena adanya gaya tarik dari bawah oleh fluida yang disebabkan oleh pompa vakum. Sehingga ketika air mengalir melewati kertas saring yang berukuran 1,5 mikrometer maka endapan yang lebih besar dari ini akan tertahan oleh kertas saring sehingga endapan akan terakumulasi di atas kertas saring.

Endapan yang telah terakumulasi pada kertas saring akan dimasukan ke dalam oven atau pemanas dengan tujuan untuk mengeringkan kertas agar berat kertas yang basah tidak menjadi suatu kesalahan dalam perhitungan TSS. Hasil perhitungan TSS menggunakan persamaan Weiner E.

$$
T S S=\frac{\text { (berat kertas dan endapannya }- \text { berat kertas kosong) } \times 1000}{\text { volume sampel }}
$$

Table 4.2 Hasil Endapan Kedua Sampel TSS

\begin{tabular}{|c|c|c|c|}
\hline Sample & $\begin{array}{c}\text { Rata-rata } \\
\text { kertas saring } \\
(\mathrm{g})\end{array}$ & $\begin{array}{c}\text { Berat rata- } \\
\text { rata } \\
(\mathrm{g})\end{array}$ & \multirow{2}{*}{ TDS } \\
\cline { 2 - 3 } & $\mathrm{A}$ & $\mathrm{B}$ & \\
\hline 1 & 1,6371 & 1,957466667 & 32036,67 \\
\hline 2 & 1,5927 & 1,833833333 & 24113,33 \\
\hline 3 & 1,584 & 1,8772 & 29320 \\
\hline 4 & 1,5911 & 1,8305 & 23940 \\
\hline 5 & 1,6044 & 1,822833333 & 21843,33 \\
\hline 6 & 1,597833333 & 1,8514 & 25356,67 \\
\hline
\end{tabular}

Hasil analisa keenam sampel tersebut didapatkan kandungan TSS minimum sebesar 258,6667 ppm. Dari nilai yang didapat jika dibandingkan dengan standar mutu air untuk diinjeksikan, maka sampel yang didapat dari PSC Odira Karang Agung belum memenuhi persyaratan, karena satndar kandungan TSS yang telah ditentukan maksimal senilai $2 \mathrm{ppm}$.

\subsubsection{Total Dissolved Solid (TDS)}

Parameter ini perlu ditentukan untuk mengetahui partikel solid yang terlarut dalam air formasi, apabila partikel yang terlarut dalam air formasi ini semakin banyak maka salinitas air formasi akan semakin besar.

Dalam menentukan padatan terlarut dalam air yang tidak tersaring kertas. Untuk mengawali uji TDS ini dilakukan penimbangan gelas ukur yang kosong pada neraca analistis yang nantinya akan digunakan sebagai selisih hasil dari partikel yang terlarut dalam gelas baker yang kosong. Tuangkan 10 ml sampel formasi ke dalam gelas ukur yang yang telah ditimbang dan di letakan pada pemanas, pemanas yang digunakan dalam analisa TDS ini adalah oven, lalu tunggu hingga gelas ukur yang terisi air formasi menjadi kering, sehingga partiket partikel yang terlarut pada sampel menjadi mengendap di dasar gelas baker, kemudian timbang kembali gelas baker yang telah kering dari pemanas.

$T D S=\frac{(\text { berat } \text { cawan telah di oven }- \text { berat cawan kosong }) \text { x } 1000}{\text { volume sampel }}$

Table 4.3 Hasil Endapan TDS

\begin{tabular}{|c|c|c|c|}
\hline Sample & $\begin{array}{c}\text { Berat kertas } \\
\text { saring }(\mathrm{g})\end{array}$ & $\begin{array}{c}\text { Berat Kertas } \\
\text { Saring }+ \\
\text { Sampel } \\
(\mathrm{g})\end{array}$ & TSS \\
\hline 1 & 0,1293 & 0,142233333 & 258,6667 \\
\hline 2 & 0,1312 & 0,1577 & 530 \\
\hline 3 & 0,130433333 & 0,1457 & 305,3333 \\
\hline 4 & 0,1325 & 0,171233333 & 774,6667 \\
\hline 5 & 0,131166667 & 0,150633333 & 389,3333 \\
\hline 6 & 0,133833333 & 0,163366667 & 590,6667 \\
\hline
\end{tabular}

Data hasil analisa keenam sampel didapatkan nilai minimum sampel TDS sebesar 21.843,33 ppm. Hal ini menunjukan bahwa kandungan solide dalam sampel ini masih sangat tinggi karena standar air bersih yang telah ditetapkan oleh pemerintah senilai $1500 \mathrm{ppm}$. 


\subsubsection{Kesadahan}

Air sadah adalah air yang mengandung calcium magnesium dan unsur garam lainnya. Tujuan penelitian kesadahan air untuk meneliti mineral mineral tertentu khususnya ion calcium dalam bentuk garam karbonat. Calcium dapat mengikat unsur carbonat dan membentuk suatu senyawa yang bersifat basa. Hal itu merugikan apabila air yang mengandung unsur calcium ikut di injeksikan. Proses penentuan kadar calcium menggunakan metode titrasi dengan larutan natrium karbonat dan natrium hidroksida dengan konsentrasi 0,1 $\mathrm{N}$ digunakan sebagai indikator. Dibutuhkan masing masing $50 \mathrm{ml}$ sampel air formasi untuk penganalisaan. Untuk mengetahui unsur calcium dan total hardness digunakan persamaan:

Untuk total hardness digunakan persamaan berikut:

$$
T H=\frac{40 \times \text { larutan EDTA }}{\text { volumme sample }}
$$

Table 4.4 Hasil Analisa Total Hardness

\begin{tabular}{|c|c|c|c|c|}
\hline \multirow{2}{*}{ Sampel } & \multicolumn{2}{|c|}{$\begin{array}{c}\text { Volume } \\
\text { EDTA (ml) }\end{array}$} & $\begin{array}{c}\text { V= }\left(\mathrm{V}_{2}-\mathrm{V}_{1}\right) \\
(\mathrm{ml})\end{array}$ & $\begin{array}{c}\text { Total } \\
\text { Hardness }\end{array}$ \\
\cline { 2 - 4 } & 1 & 2 & & \\
\hline 1 & 1,2 & 3,3 & 2,1 & 0,84 \\
\hline 2 & 6,6 & 9,5 & 2,9 & 1,16 \\
\hline 3 & 9,5 & 13,4 & 3,9 & 1,56 \\
\hline 4 & 13,4 & 18,2 & 4,8 & 1,92 \\
\hline 5 & 18,2 & 20,6 & 2,4 & 0,96 \\
\hline 6 & 20,6 & 23,25 & 2,65 & 1,06 \\
\hline
\end{tabular}

Dari hasil analisa kesadahan total keenam sampel didapatkan nilai minimum yang diperoleh sebesar 0,84 ppm. Ini memenuhi persyaratan batas maksimal kesadahan pada air, karena kesadahan yang ditentukan senilai $500 \mathrm{ppm}$.

Untuk menentukan Calcium hardness digunakan persamaan berikut:

$$
C a=\frac{40 \times \text { larutan EDTA }}{\text { volumme sample }}
$$

Hasil analisa kesadahan calsium keenam sampel didapatkan nilai minimum sebesar 0,1 ppm. Ini memenuhi persyaratan batas maksimal kesadahan total pada air, karena kesadahan yang ditentukan senilai 500 ppm.

\begin{tabular}{|c|c|c|c|c|}
\hline \multirow[t]{2}{*}{ Sampel } & \multicolumn{2}{|c|}{$\begin{array}{c}\text { Volume } \\
\text { EDTA } \\
(\mathrm{ml})\end{array}$} & \multirow[t]{2}{*}{$\begin{aligned} \mathrm{V}= & \left(\mathrm{V}_{2}-\mathrm{V}_{1}\right) \\
& (\mathrm{ml})\end{aligned}$} & \multirow[t]{2}{*}{$\begin{array}{l}\text { Calcium } \\
\text { Hardness }\end{array}$} \\
\hline & 1 & 2 & & \\
\hline 1 & 1 & 1,75 & 0,75 & 0,3 \\
\hline 2 & 1,75 & 2,25 & 0,5 & 0,2 \\
\hline 3 & 2,25 & 2,5 & 0,25 & 0,1 \\
\hline 4 & 2,5 & 2,9 & 0,4 & 0,16 \\
\hline 5 & 2,9 & 3,4 & 0,5 & 0,2 \\
\hline 6 & 3,4 & 3,7 & 0,3 & 0,12 \\
\hline
\end{tabular}

Table 4.5 Hasil Analisa Calcium Hardness

\subsubsection{Dissolved Oxygen}

Oksigen terlarut (dissolved oxygen, disingkat DO) atau sering juga disebut dengan kebutuhan oksigen (oxygen demand) merupakan salah satu parameter penting dalam analisis kualitas air. Nilai DO yang biasanya diukur dalam bentuk konsentrasi ini menunjukan jumlah oksigen $\left(\mathrm{O}_{2}\right)$ yang tersedia dalam suatu badan air. Semakin besar nilai DO pada air, mengindikasikan air tersebut memiliki kualitas yang bagus. Sebaliknya jika nilai DO rendah, dapat diketahui bahwa air tersebut telah tercemar. Pengukuran DO juga bertujuan melihat sejauh mana badan air mampu menampung biota air seperti ikan dan mikroorganisme. Selain itu, kemampuan air untuk membersihkan pencemaran juga ditentukan oleh banyaknya oksigen dalam air.

Oksigen merupakan unsur yang ada dalam air formasi yang dapat mengoksidasi peralatan. Sehingga peralatan yang teroksidasi dapat mengakibatkan perkaratan, dan minyak merembes keluaar. Dalam penentuan untuk menentukan unsur oksigen yang terdapat pada air formasi dilakukan dengan cara menambahkan $1 \mathrm{ml} \mathrm{HCl}$ pekat, dengan ujung pipet tercelup dalam larutan. Kocok hingga endapan larut dan cair berwarna kuning. Diamkan selama 10 menit. Pipet $100 \mathrm{ml}$ larutan contoh, masukkan ke dalam erlenmeyer $250 \mathrm{ml}$. tambahkan 10 tetes larutan amilum dan kocok. Titrasi dengan larutan natrium sulfit sampai tepat berwarna biru 
hilang. Catat volum natrium sulfit yang digunakan.

$$
\mathrm{O}_{2}=\frac{\text { volume titrasi } \mathrm{x} 0,2 \times 1000}{\text { volume sample }}
$$

Table 4.6 Hasil Analisa Dissolved Oxygen

\begin{tabular}{|c|c|c|c|c|}
\hline Sampel & $\begin{array}{c}\text { Volume } \\
\mathrm{Na}_{2} \mathrm{~S}_{2} \mathrm{O}_{3} \\
\mathrm{~V}_{1} \\
(\mathrm{ml})\end{array}$ & $\begin{array}{c}\mathrm{V}_{2} \\
(\mathrm{ml})\end{array}$ & $\begin{array}{c}\mathrm{V}=\left(\mathrm{V}_{2}-\mathrm{V}_{1}\right) \\
(\mathrm{ml})\end{array}$ & $\begin{array}{c}\text { Dissolve } \\
\text { d Oxigen } \\
(\mathrm{ppm})\end{array}$ \\
\hline 1 & 4,3 & 5,1 & 0,8 & 1,6 \\
\hline 2 & 7,3 & 8,4 & 1,1 & 2,2 \\
\hline 3 & 8,4 & 11 & 2,6 & 5,2 \\
\hline 4 & 11 & 12,8 & 1,8 & 3,6 \\
\hline 5 & 12,8 & 14,3 & 1,5 & 3 \\
\hline 6 & 14,3 & 16,25 & 1,95 & 3,9 \\
\hline
\end{tabular}

Setelah analisa dissolved oxygen dilakukan, hasil menunjukan bahwa keenam sampel memiliki kandungan minimum dissolved oxygen sebesar 1,6 ppm. Hasil ini memberitahukan bahwa sampel air formasi dari PSC Odira Karang Agung belum memenuhi standar mutu air bersih karena batasnya melebihi 0,2 ppm.

\subsubsection{Hasil Analisa Air formasi}

Berdasarkan analisa yang telah dilakukan pada keenam sampel ini dapat disimpulkan bahwa air yang telah dianalisa belum memenuhi standar mutu untuk diinjeksikan kembali. Ini dikarenakan, dari beberapa parameter yang dilakukan analisa, untuk TDS, TSS, dan DO nilai yang diperoleh lebih tinggi dari yang telah ditetapkan oleh pemerintah.

\section{KESIMPULAN DAN SARAN}

\subsection{Kesimpulan}

Dari hasil pengujian dan analisa yang telah dilakukan terhadap sampel dari lapangan, diperoleh kesimpulan bahwa air injeksi yang terdapat di PSC Odira Energi Karang Agung belum memenuhi standar sebagai air injeksi. Ini dikarenakan dari beberapa parameter yang dilakukan analisa, untuk TDS, TSS, dan DO nilai yang diperoleh lebih tinggi dari yang telah ditetapkan oleh pemerintah.
Penelitian ini dilakukan di Laboratorium Politeknik Akamigas Palembang, sehingga untuk pemilihan parameter uji dilakukan dengan menyesuaikan ketersediaan jumlah sampel serta parameter uji dan peralatan yang tersedia. Sehingga beberapa parameter penting dalam analisa kualitas air injeksi lainnya tidak dilakukan. Untuk itu, perlu dilakukan penelitian lanjutan untuk dapat mengetahui parameter lain yang belum dilakukan analisa.

\section{DAFTAR PUSTAKA}

Allan, Thomas. O dan Roberts, Allan. P., 1979. Production Operation (Vol 2), Oil and Gas ConsultantInc, Tulsa.

Andarani, Pertiwi dan Rezagama A. 2015. Analisis Pengolahan Air Terproduksi Di Water Treating Plant Perusahaan Eksploitasi Minyak Bumi. Jurnal Presipitasi. Vol. 12 (2), 78 - 85. http://ejournal.undip.ac.id/index.php/ diakses tanggal 12 Juli 2017.

Crabtree, Mike., Eslinger, David., dkk, 1999 Fighting Scale, Removal, and Prevention, Schlumberger, Texas.

IATMI SM STT MIGAS Balikpapan. 2012. Pengantar Studi Water Flood. https://iatmismmigas.wordpress.com/2012/06/ 07/pengantar-studi-water-flood/ diakses tanggal 12 Juli 2017.

JOB Pertamina - Jadestone Energy (OK), Ltd. Standard Operation Procedure Analisa Oil Contents (OC). Baturaja. JOB Pertamina Jadestone Energy (OK), Ltd..

James W., Amyx dan Bass. Jr., Daniel. Petroleum Reservoir Engineering : Physical Properties.

Maulana, Hardi. 2017. Karakteristik Terproduksi Industri Migas Sebagai Sumber Daya Air Alternatif Di Kecamatan Minas, Kabupaten Siak, Riau. Prosiding Seminar Nasional Pelestarian Lingkungan (Senpling).

\subsection{Saran}


Yuniarto. Limbah Cair Panas Bumi dan Dampaknya Terhadap Lingkungan. Jurnal Matematika, Saint dan Teknologi, Volume 17,

Nomor 2 September 2016, 99-108. 
P-ISSN: 2089-5925 E-ISSN: 2621-9328

A

Jurnal Teknik Patra Akademika

PATRA

Arademika

Volume 11 No. 02 Desember 2020 